\title{
Real Wage Rate And Productivity Relationship In The Declining U.S. Steel Industry
}

Amaechi Nkemakolem Nwaokoro, (E-mail: anwaokoro@yahoo.com), Morehouse College

\begin{abstract}
This study examines the relationship between the real wage rate and productivity in the U.S. steel industry in the critical period of 1963-1988. This period witnessed a declining steel output and employment, increasing productivity, and a slight increasing real wage rate. The severity of the decline was felt in the 1980s. The popular explanation focuses on the nominal wage rate relative to productivity (non-nominal value). The study is based on high-frequency monthly data set on output, employment, productivity, wage rate, factor prices, and national unemployment rate. Also control factors are constructed for the steel import protection and non-protection regimes. Some econometric modeling issues are addressed. Recognizing that productivity is stochastic and is potentially an endogenous variable, it is instrumented with a set of productivity-related variables including controls for various steel protection and non-protection regimes. Third, the wage in the industry is modeled as a function of exogenous productivity, price of steel products, national unemployment rate, and real interest rate. Serial correlation characterizes the data, and this is corrected with inter-temporal effect of the real wage rate, and with a differencing model. The main results of the study are threefold. First, OLS and Instrumental Variable (IV) estimates show that productivity is the key variable for explaining the real wage rate. Second, like in the literature, the study finds that heavy and autonomous capitalization has an impact on the rising productivity. Third, the study identifies an inter-temporal high real wage rate as the driving factor for explaining the short run real wage rate. These results are somewhat sensitive across specifications.
\end{abstract}

\section{INTRODUCTION}

$T$

his study covers a critical period (1963-1988) in the history of U.S. steel industry. The period witnessed declining steel output and employment, increasing productivity, a slight increasing real wage rate, multiple steel protection and non-protection regimes, and overcapitalization. The protection regimes are intended to restrict steel imports, thereby boosting output and employment that are used for constructing the productivity. Without using estimation procedures, Barnett \& Schorsch, 1983, for example, explains the industry's nominal wage rate by productivity (output per worker). Nominal wage rate could be rising without being influenced by productivity (non-nominal values).

Heavy and autonomous capitalization in the industry is noted to have impact on productivity. Investments leading to capital expansion in the 1950s led to a heavy capitalization, and technology was not upgraded (Barnett \& Schorsch 1983, pp. 13, 27). As foreign competitors increased their use of modern technologies (especially the Japanese investments in continuous casting technology in the 1980s), the U.S steel industry was challenged to invest in similar technologies (Hogan, 1983, pp. 6-7, 77, 80, 108-109). With these technical changes U.S. steel used a lot of capital and technology, which boosted productivity. During the period in study, compensation for labor increased by $3.14 \%$ while compensation for capital increased by $5.94 \%$. These stylized facts seem to indicate that capital has an enhancing impact on the productivity ${ }^{1}$. 
As the industry experiences overcapitalization, growing foreign competition may have had a strong impact on steel output. Responding to the declining output, the industry's employment decreased and led to a high productivity. An increasing use of steel substitutes by steel users may have had adverse impact on steel output that in turn affects productivity. And yet another factor that may have impacted on productivity is other shipments (non-steel shipments). This is a proxy for the expansion and contraction of the economy.

In this paper, the view is that increasing real wage rate is in part driven by productivity. The notion here is that as foreign competition imposes greater adverse impact on employment than it does on output, as the economy expands, and as steel substitutes is increasingly being used, productivity increases. The rising productivity in turn causes variation in the real wage rate. The study also introduces other factors-price of steel products, national unemployment rate, and real interest rate that may have affected or shifted the wage/productivity relationship. Intertemporal effect of the high real wage rate on the current real wage rate is also considered.

The rising real wage rate is examined by estimating exogenous productivity, the price of steel products, national unemployment rate, and real interest rate in a wage equation. To capture the inter-temporal effect of the real wage rate, the lag of the real wage rate is introduced in the equation. This explains the short run wage adjustment. In this research, I use national unemployment rate and interest rate as shock proxies for wage adjustment. The notion here is to investigate the substitutability among factors.

The remainder of this study has three sections. Section II presents the theoretical and basic econometric specifications for wage and for productivity. In section III, discussion centers on the data and measurement issues. In section IV, the estimates are discussed. This work relates to wage theories of Shapiro and Stiglitz 1984, Black and Garen 1991, Weiss 1980, Gilder 1992, and Golub (1995).

The study finds interesting results. The study finds that productivity characterizes the real wage rate in the industry; though the results differ across model specifications. In most model specifications, the price of steel products has positive impact on the real wage rate. Although the estimates of interest rate are not statistically significant, they give clue that capital and labor are compliments. In most model specifications, unemployment rate shows that increasing unemployment rate will tend to cause a decrease in the quantity demanded of steel labor and wage will tend to rise. As is usually the case, in the short model, the current real wage rate is explained by the past real wage rate.

\section{THEORETICAL AND BASIC ECONOMETRIC SPECIFICATIONS}

The current production real wage rate, $\mathrm{w}_{\mathrm{t}}$ can be expressed as a function of the productivity, $\mathrm{Q}$, of the price of steel products (Ps), of the national unemployment rate (un), and of real interest rate (r), The general functional form can be stated as:

$w_{t}=f(Q, P s$, un, $r)$.

(1)

Equation (1) harbors an endogeneity problem when the actual output instead of the planned output from the firm's cost minimization problem is used for constructing the productivity. Planned output may differ from the actual output by idle time caused by machine breakdown, inaccurate measures of demand, strikes, and input shortages (Dunne \& Roberts, 1993). In an econometric specification, the study uses the Standard Errors in Variable Model (EVM) to correct for the productivity-associated endogeneity issue. The appropriate standard errors are constructed for the model as explained in Murphy \& Topel (1985) $)^{2}$.

The period $t$ planned or exogenous productivity is stated as $\mathrm{Q}^{*}$ given the assumption that the planned productivity-associated error term, $v_{t}$, follows $\mathrm{N}\left(0, \delta_{t}^{2}\right)$ distribution. It is assumed that the measurement errors are uncorrelated with the planned productivity. The observed productivity, $\mathrm{Q}$, at period $t$ can therefore be stated as: 
$\underline{2}$

$Q=Q^{*}+v_{t}$

(2)

The observed productivity variable-associated measurement errors cause the productivity in equation (1) to be stochastic (Dunne \& Roberts, 1993). By using an instrumental variables (IV) approach, this problem is resolved. With this, the reduced form productivity equation can be stated as:

$\hat{Q}=f\left(Z, O_{S}, P_{A}, P_{R A}\right)$

(3)

where $\mathrm{Z}$ controls for the steel import protection and non-protection regimes, and $\mathrm{O}_{\mathrm{S}}, \mathrm{P}_{\mathrm{A}}$, and $\mathrm{P}_{\mathrm{RA}}$ are respectively other shipments (non-steel shipments), the price of aluminum, and the price of rubber and plastic. With the planned productivity given by the predicted productivity, $\hat{Q}$, the wage equation can now be restated as:

$w_{t}=f(\hat{Q}, P s, u n, r)$

(4)

Now productivity is exogenous variable.

Econometric Productivity Specifications: The steel actual output per worker (productivity (Q)) empirical equation is linearly stated in period $t$ as:

$\log Q_{t}=\alpha+\alpha_{1} \log Q_{t-1}+\alpha_{2} \log O_{s t}+\alpha_{4} \log P_{A}+\alpha_{5} \log P_{R A}+\sum \gamma_{i} D Z_{i}+\mu$

where $\alpha_{\mathrm{i}}, \mathrm{i}=0, . ., 5$ and $\gamma_{\mathrm{i}}, \mathrm{i}=1, \ldots \ldots . ., 10$ are parameters for the dummy variables of the different steel protection and non-protection regimes ${ }^{3}$, and $u_{\mathrm{t}}$ is the error term.

Econometric Wage Specification: Given the predicted productivity, $\hat{Q}$ from equation 5 , an empirical wage equation is specified in period $t$ as:

$\log w_{t}=\beta+\beta_{1} \log \hat{Q}_{t}+\beta_{2} \log P s+\beta_{3} u n+\beta_{4} r+\eta_{t}$

(6)

where $\eta_{\mathrm{t}}$ is the error term ${ }^{4}$. OLS results are provided to make comparison to the other appropriate alternative estimation techniques. First, a basic model that includes the real wage rate and productivity is estimated. This model is altered to include some other factor or factors. Caution has to be exercised while interpreting the OLS results.

\section{DATA AND MEASUREMENT ISSUES}

The data on monthly variables that describe steel mill productivity cover the period from 1963 to 1988. These variables are available from several sources. The output variable is the production of steel mill products. The employment variable is the production employment. The production workers wage rate variable is obtained by dividing the total compensation cost and all fringe benefits by the weekly production hours.

The AAA-rated corporate bond yield ${ }^{5}$ is a proxy for the cost of capital. I constructed the price indices for aluminum (SIC 3334), rubber and plastic goods (SIC 30), steel mill products (SIC 3312), and also the non-steel shipments and steel protection variables ${ }^{6}$. The wage rate variable is deflated with CPI, and steel shipment variables are deflated using a steel price index. Also, I constructed the real interest rate and appropriately deflated the other variables used in this study ${ }^{7}$. The descriptive statistics of the major series are presented in Table 1. 
Figure 1 shows the time series plots from the relative values ${ }^{8}$ for steel output, employment, and productivity. In examining the steel output series, there are two periods of marked contraction-1974-1975 and 1979-1982. In both periods, steel production declined substantially but the contraction is striking in the 1979-1982 period. The average annual growth rate in steel production between 1963 and 1975 was $1.05 \%$. This growth rate dropped to $-0.04 \%$ between 1976 and 1988. Also steel employment started to decline during the marked output contraction periods. From the 1979 through 1988, employment in steel declined by $-7.49 \%$.

Table 1: Summary Statistics

\begin{tabular}{|l|c|c|c|}
\hline \multicolumn{1}{|c|}{ Variable Name } & Mean & Standard Deviation & Interquatile Range \\
\hline Output (millions net tons) $^{1}$ & 9.809 & 1.766 & 3.471 \\
\hline Indexed Price of steel Products $^{2}$ & 63.20 & 29.06 & 68.46 \\
\hline Production Employment $^{2}$ (thousands) & 0.349 & 0.090 & 0.187 \\
\hline Real Wage Rate & $\$ 12.42$ & 1.11 & 2.40 \\
\hline Productivity & 30.18 & 5.56 & 5.52 \\
\hline Observations: 312 & & & \\
\hline
\end{tabular}

${ }^{1}$ Metal Statistics 1969, 1974, 1979, 1984 and 1990 series, American Metal Market.

${ }^{2} 1909-1990$ issue of the U.S. Employment and Earnings Survey Data, U.S. Department of Labor.

${ }^{3}$ U.S. Employment and Earnings Survey Data, 1909-1990 issue, U.S. Department of Labor.

Figure 1: Time Series of Labor Productivity, Output, and Employment

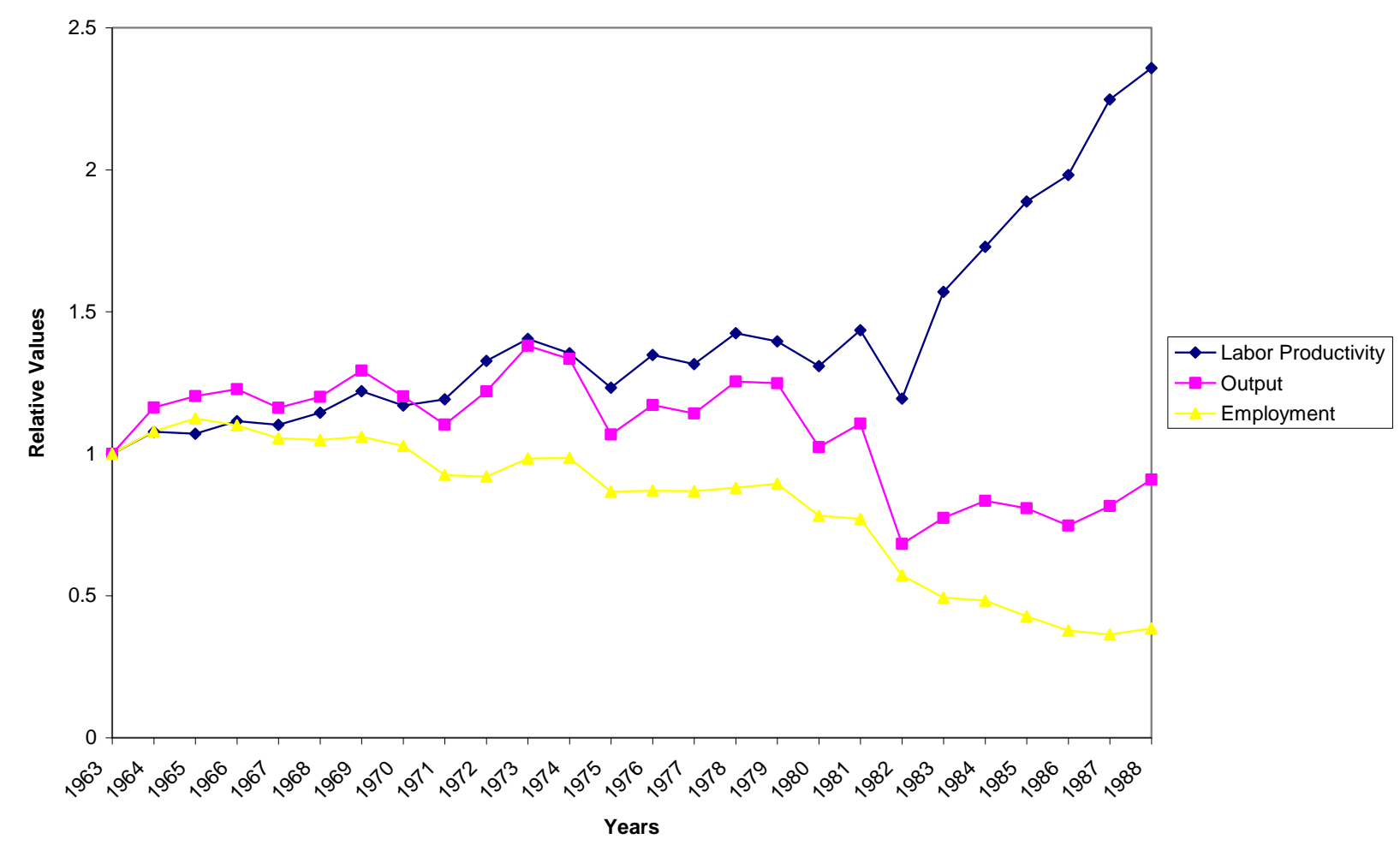

Generally, before 1982, the labor efficiency factor exhibits an increasing trend, which becomes very sharp after 1982. The sharp increase implies that employment declines faster than output during the period. 
Figure 2 shows the time series plots from the relative values for real wage rate, labor productivity, steel price, and national unemployment rate. The slight increasing trend of the real wage rate till 1982 when it starts to decline shows that the real wage rate is driven by increasing productivity. For the later period, the declining real wage rate seems to be explained by the severity of the declining output and labor demand, and by the effect of overcapitalization.

The price of steel has an increasing trend which becomes very sharp after 1973. After 1982 the real wage rate declines in the face of increasing trend of the price of steel. The national unemployment rate shows up and down trend. Generally, this factor seems to have a modest influence on the real wage rate.

\section{Figure 2: Time Series of Real Wage Rate, Labor Productivity, Steel Indexed Price, and National Unemployment Rate}

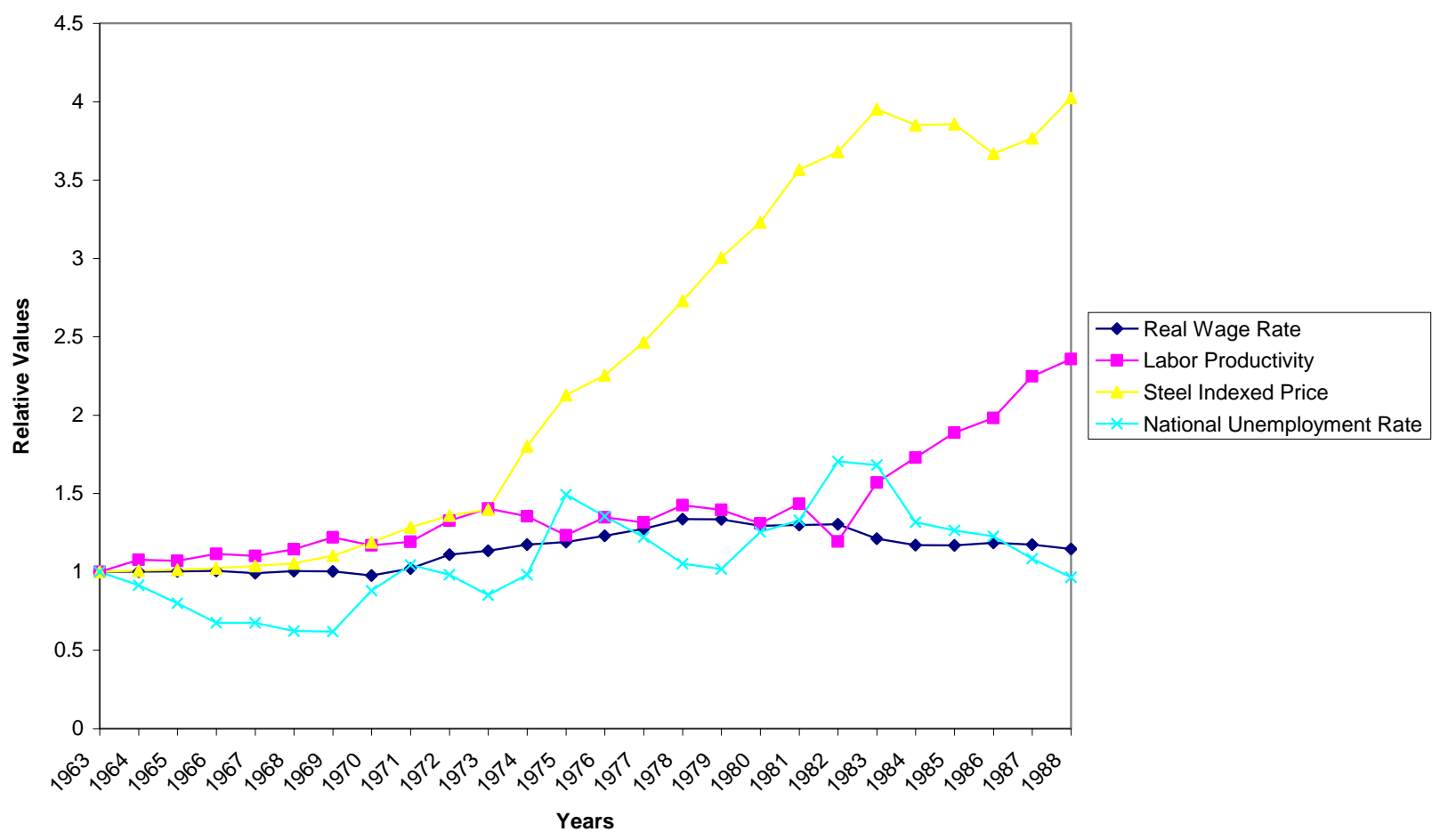

\section{REGRESSION RESULTS FROM THE OLS AND IV MODELS}

The OLS and IV estimates from equation (6) are reported in Table 2. Recalling that the OLS model gives biased estimates, the results need to be interpreted with caution. The IV models correct the biased estimate problem.

Detailed Result from IV Estimation Technique ${ }^{9}$ : The first two columns of Table 2 report the results from the OLS and IV estimation procedures. There is no correction for serial correlation in the results. The efficiency estimates are somewhat inelastic and are comparable to the consistent IV estimates. The national unemployment rate has a positive impact on the real wage rate. A note of caution here is warranted. The DW statistic clearly indicates the presence of serial correlation in the error term.

Column 3 includes the national unemployment rate, column 4 includes unemployment and real interest rates, and column 5 includes unemployment and real interest rates, and price of steel products. In these columns the estimates of national unemployment rate imply that during a period of increasing national unemployment rate, the quantity of steel labor decreases and the real wage rate tends to increase. This is an indication that the steel real wage rate is sticky downward. Due to overcapitalization, the estimate of real interest rate is not statistically significant, but it gives 
$\underline{2}$ some clue that capital and labor seem to be compliments. As expected the estimate of the price of steel products explains that the real wage rate increases with increase in the price of steel products.

As is usually the case, in the short run model, the past real wage rate is dominant in the explanation of the current real wage rate. In the Difference (Diff) model $^{10}$, the data variation is substantially reduced and makes the estimates of the variables to be very inelastic. The statistically insignificant and negative estimate of productivity in the Difference model implies an extreme situation whereby the output is mostly enhanced by the existing capitalization. This leads to a decline of the real wage rate as the demand for labor declines. Notice that in both the short run and Difference models, that the problem of the serial correlation is resolved. In both columns, the DW statistics converge to the values for the rejection of serial correlation.

Table 2: Production Worker Wage Estimates from OLS and IV Models (Asymptotic Standard Error in Parentheses)

\begin{tabular}{|c|c|c|c|c|c|c|c|}
\hline & 1 & 2 & 3 & 4 & 5 & 6 & 7 \\
\hline $\begin{array}{l}\text { Explanator } \\
\text { y Variable }\end{array}$ & $\begin{array}{c}\text { OLS Basic } \\
\text { Model }\end{array}$ & $\begin{array}{c}\text { IV Basic } \\
\text { model }\end{array}$ & $\begin{array}{c}\text { IV Basic } \\
\text { model with } \\
\text { un }\end{array}$ & $\begin{array}{c}\text { IV Basic } \\
\text { model with } \\
\text { un, } \mathbf{r} \\
\end{array}$ & $\begin{array}{c}\text { IV Basic } \\
\text { model with } \\
\text { un, r, Ps }\end{array}$ & $\begin{array}{c}\text { IV Basic } \\
\text { model with } \\
\text { un, r, Ps, } w_{t-1}\end{array}$ & $\begin{array}{c}\text { IV Diff model } \\
\text { with un, r, Ps, } \\
w_{t-1}\end{array}$ \\
\hline $\begin{array}{c}\text { Constant } \\
\text { Term }\end{array}$ & $\begin{array}{c}1.901 \\
(0.079)\end{array}$ & $\begin{array}{c}1.864 \\
(0.083)\end{array}$ & $\begin{array}{c}1.908 \\
(0.063)\end{array}$ & $\begin{array}{l}1.608^{*} \\
(0.059)\end{array}$ & $\begin{array}{l}2.099 * \\
(0.049)\end{array}$ & $\begin{array}{l}0.107^{*} \\
(0.044)\end{array}$ & $\begin{array}{l}0.015^{*} \\
(0.010)\end{array}$ \\
\hline $\log \hat{Q}$ & & $\begin{array}{l}0.192^{*} \\
(0.024)\end{array}$ & $\begin{array}{l}0.110^{*} \\
(0.019)\end{array}$ & $\begin{array}{l}0.198^{*} \\
(0.018)\end{array}$ & $\begin{array}{l}-0.141 * \\
(0.022)\end{array}$ & $\begin{array}{l}-0.015^{*} \\
(0.007)\end{array}$ & $\begin{array}{l}-0.006^{*} \\
(0.004)\end{array}$ \\
\hline $\log Q$ & $\begin{array}{l}0.181^{*} \\
(0.023)\end{array}$ & & & & & & \\
\hline Log Ps & & & & & $\begin{array}{l}0.225^{*} \\
(0.012) \\
\end{array}$ & $\begin{array}{l}0.011^{*} \\
(0.006) \\
\end{array}$ & $\begin{array}{l}-0.018 \\
(0.067) \\
\end{array}$ \\
\hline un & & & $\begin{array}{l}0.038^{*} \\
(0.003)\end{array}$ & $\begin{array}{l}0.046^{*} \\
(0.002)\end{array}$ & $\begin{array}{l}0.003^{*} \\
(0.003)\end{array}$ & $\begin{array}{l}-0.001 * \\
(0.001)\end{array}$ & $\begin{array}{l}0.001^{*} \\
(0.003)\end{array}$ \\
\hline $\mathrm{r}$ & & & & $\begin{array}{l}-0.014 * \\
(0.001) \\
\end{array}$ & $\begin{array}{l}-0.011^{*} \\
(0.001) \\
\end{array}$ & $\begin{array}{l}-0.0002 * \\
(0.0003) \\
\end{array}$ & $\begin{array}{l}0.003^{*} \\
(0.001) \\
\end{array}$ \\
\hline $\log w_{t-1}$ & & & & & & $\begin{array}{c}0.961 * \\
(0.020)\end{array}$ & \\
\hline$\overline{\mathrm{R}}^{2}$ & 0.159 & 0.166 & 0.521 & 0.665 & 0.844 & 0.981 & 0.051 \\
\hline DW & 0.052 & 0.037 & 0.057 & 0.189 & 0.276 & 2.332 & 2.342 \\
\hline Rho & 0.971 & 0.979 & 0.969 & 0.903 & 0.857 & -0.168 & -0.171 \\
\hline Sample size & 312 & 308 & 308 & 308 & 308 & 308 & 307 \\
\hline
\end{tabular}

*Denotes estimates that are statistically significant at the marginal probability $(\mathrm{P}=0.05)$ level.

In summary, this study is successful in generating consistent real wage rate estimates from a high frequency monthly industry-level data set. This kind of data is better suited for characterizing the wage decisions. Without a detailed study, previous studies concentrated on associating nominal wage rate with productivity. In addition, this study introduces into the wage models, other factors - national unemployment and interest rates, and price of steel products variables that also describe the real wage rate paid in the steel industry. A rising national unemployment rate has adverse impact on the quantity demanded of steel labor and this will cause the real wage rate to rise. Increasing price of steel products has a positive effect on the real wage rate. Given overcapitalization, interest rate does not have an appreciable effect on the real wage rate. The magnitude of the explanations given by these variables differs across model specifications. Previous work did not specify these factors in the empirical wage equation.

\section{Suggestion for Future Research}

A comparative study based on steel productivity and real wages from the US and from other industrially advanced countries experiencing steel industry decline is warranted. A comparative study of steel union and non-union 
real wages would help in the determination of how much the union real wage exceeds the non-union real wage. A comparative study from various countries is also needed to find out steel wage/price relationship. U.S. steel consumers could be better off buying imported steel from the countries where steel wages and prices are lower relative to the U.S. This could highlight the gains or losses in societal welfare relative to U.S. wage/price relation.

\section{REFERENCES}

1. American Metal Market. 1969, 1974, 1979, 1984, and 1990. Metal Statistics. American Metal Market. New York.

2. Barnett, Donald F. and Louis Schorsch. 1983. Steel: Upheaveal in a Basic Industry. Ballinger Publishing Company. Cambridge, Massachusetts.

3. Bartelsman, Eric and Wayne Gray. 1994. NBER Manufacturing Productivity Database. Working Paper.

4. $\quad$ Black, Dan A. and John E. Garen. 1991. Efficiency Wages and Equilibrium Wages Economic Inquiry, 525-540.

5. Dunne, Timothy and Mark J. Roberts. 1993. The Long-Run Demand for Labor: Estimates from Census Establishment Data. U.S. Department of Commerce. Washington, D.C.

6. Gilder, George. 1992. Recapturing The of Spirit of Enterprise, ICS Press, San Francisco, California.

7. Golub, Stephen 1995. Productivity and Labor Cost in Newly Industrialized Countries. FRBSF Weekly Letter, Federal Reserve Bank of San Francisco.

8. Hogan, William T. 1983. World Steel in the 1980s: A Case of Survival. Lexington Books, D.C. Heath and Company. Lexington, Massachusetts.

9. Murphy, Kevin M. and Robert H. Topel. 1985. Estimation and Inference in Two-Step Econometric Models. Journal of Business and Economic Statistics, 3:370-379.

10. SAS/ETS. User's Guide, Version 6, 2nd edition. SAS Institute Inc., Cary, North Carolina.

11. Shapiro, Carl and Joseph Stiglitz. 1984. Equilibrium Unemployment as A Worker Discipline Device, American Economic Review, 433-444.

12. United States Government Printing Office. 1964-1990. Economic Report of the President. United States Government Printing Office. Washington, D.C.

13. U.S. Department of Commerce: Bureau of the Census 1958-1977, 1977-1982 and 1982-1990. Current Industrial Reports: Manufacturers' Shipments, Inventories and Orders. U.S. Department of Commerce: Bureau of the Census. Washington, D.C.

14. U.S. Department of Labor: Bureau of Labor Statistics.1991. U.S. Employment and Earnings Survey Data. U.S. Department of Labor: Bureau of Labor Statistics. Washington, D.C.

15. U.S. Department of Labor 1969-1989. Monthly Labor Review. U.S. Department of Labor. Washington, D.C.

16. U.S. Department of Labor 1963-1967. Wholesale Prices and Price Indexes. U.S. Department of Labor. Washington, D.C.

17. Weiss, Andrew 1980. Job Queues and Layoffs in Labor Market with Flexible Wages. Journal of Political Econoy.

\section{ENDNOTES}

\footnotetext{
${ }^{1}$ The calculations are based on cost information and indexed investment price deflator from Manufacturing Productivity Data (MP).

${ }^{2}$ The problem with using the predicted value as an independent variable is its randomness. Since the predicting factors are drawn from the random samples of their respective populations, the predicted value will have a stochastic component. This will violate a vital assumption concerning non-stochastic independent variables in the OLS estimation technique. The standard errors from the instrumental variable estimator are therefore inflated, depending on the ratio of the error terms from the output and employment models. Thus, the instrumental variable estimator loses efficiency but is consistent in large samples.

${ }^{3}$ Below are the specific regime, protection policy, and the associated dummy variable.
} 
Table 2: Steel Protection Regimes

\begin{tabular}{|c|c|c|}
\hline Specific Policy Regime & Protection Policy & Dummy Variable \\
\hline January 1963-December 1968 & Free Trade & $\mathrm{DZ}_{1}$ \\
\hline January 1969-December 1971 & VRAs & $\mathrm{DZ}_{2}$ \\
\hline January 1972-December 1974 & VRAs & $\mathrm{DZ}_{3}$ \\
\hline January 1975-May 1976 & No Policy & $\mathrm{DZ}_{4}$ \\
\hline June 1976-April 1978 & Specialty Steel Quotas & $\mathrm{DZ}_{5}$ \\
\hline May 1978-February 1980 & TPM \& Specialty Steel Quotas & $\mathrm{DZ}_{6}$ \\
\hline March 1980-January 1982 & TPM & $\mathrm{DZ}_{7}$ \\
\hline February 1982-October 1982 & No Policy & $\mathrm{DZ}_{8}$ \\
\hline November 1982-July 1983 & European VRAs & $\mathrm{DZ}_{9}$ \\
\hline August 1983-July 1985 & European VRAs \& Specialty Steel & $\mathrm{DZ}_{10}$ \\
\hline August 1985-December 1988 & VRAs \& Specialty Steel Quotas & \\
\hline
\end{tabular}

${ }^{4}$ In Dunne \& Roberts (1993), $\eta_{\mathrm{t}}=-\beta_{\mathrm{Q}} v_{\mathrm{t}}+\varepsilon_{\mathrm{t}}$ where $\beta_{\mathrm{Q}}$ denotes the output coefficient and $\varepsilon_{\mathrm{t}}$ is the pure random shock in the empirical labor demand equation. Each of the error terms in $\eta_{\mathrm{t}}$ is assumed to be random, possesses zero mean, a constant variance and is uncorrelated with any other error term. Errors associated with measurement are assumed to be correlated with the deterministic variables of the estimating model.

${ }^{5}$ (Source: 1966-1990 issues of the Economic Report of the President).

${ }^{6}$ The indexed prices are constructed from the WPI 1963-1967, and PPI 1969-1989 of the Monthly Labor Review. Measured in millions of dollars, the non-steel shipments variable, a proxy for steel demand, is the total U.S. manufacturing shipments minus the steel shipments. (Sources: 1958-1977, 1977-1982, 1982-1990 Current Industrial Report series. The steel protection variables are qualitative and attempt to control for the various trade-protection regimes. Both the industrial goods price and the Consumer Price Index (CPI) are respectively retrieved from the 1965 to 1990, and 1964 to 1990 series of the Economic Report of the President.

${ }^{7}$ The constructed real interest rate is, $\mathrm{r}_{\mathrm{t}}=\mathrm{i}_{\mathrm{t}}-\Delta \mathrm{P}_{\mathrm{t}}$ where $\Delta \mathrm{P}_{\mathrm{t}}$ is $\left(\mathrm{P}_{\mathrm{t}}-\mathrm{P}_{\mathrm{t}-12}\right) / \mathrm{P}_{\mathrm{t}-12}$ and $\mathrm{i}$ is the nominal interest rate. The relevant indexed prices and the non-steel shipments variables are deflated by the industrial indexed price.

${ }^{8}$ Define a relative value as $X_{t} / X_{1963}$ where $X_{t}$ is the observation of period $t$ and $X_{1963}$ is the base year's observation.

${ }^{9}$ This paper uses SAS/ETS User's Guide estimation procedures. Before running a regression on the wage equation, the dummies for the steel protection instruments and "no policy" in the first stage IV estimation model are jointly tested in the F-test for their significance in the model. This test finds the estimates of these variables to be jointly significant. The prices of steel substitute materials are not significant in the F-test. The other shipments variable and its lags have a positive effect on productivity. The $\mathrm{R}^{2}$ (0.914) is high, and with DW (2.135), there is rejection of serial correlation. The full regression results are available from the author by request.

${ }^{10}$ The Differencing (Diff) approach uses first difference to correct for the serial correlation, time trend and multicollinearity problems. Data is available upon request. 